\title{
Primjena endofitnih Fusarium gljiva \\ za poboljšanje rasta vinove loze
}

\section{Sažetak}

Endofitni organizmi se sve više primjenjuju u ekološkoj proizvodnji i zaštiti biljaka. Najčešće se radi o gljivama i bakterijama koje se apliciraju na biljke kao biološka sredstva za poboljšanje rastai otpornostina biljne bolesti. U našem istraživanju preliminarno smo ispitali utjecaj dva izolata gljive Fusarium solani na porast vinove loze sorte Kardinal i Lavalle. Vinova loza je tretirana sa suspenzijomgljive u stadiju pupa. Dva mjeseca nakon umjetne infekcije izmjerene su karakteristike vinove loze: dužina stabljike te dužina, širina i broj listova. Utvrđen je značajan pozitivan utjecaj endofitnih gljiva na dimenzije stabljike i lista. Zaključili smo da endofitne gljive pozitivno djeluju na ukupno zdravstveno stanje biljke što indirektno smanjuje mogućnost pojave bolesti jer su biljke otpornije.

Ključne riječi: endofiti, gljive, poboljšanje rasta, vinova loza

\section{Uvod}

U današnje vrijeme sve se više govori o mikrobiološkom inženjeringu koji predstavlja unošenje mikroorganizama u biljke kako bi se poboljšao njihov razvitak te otpornost na nepovoljne uvjete okoliša i štetne organizme (del Carmen Orozco-Mosquedai i sur., 2018). U skladu s tim je i pojam mikrobiom koji predstavlja zajednicu mikroorganizama unutar biljke. Za razliku od genetskog inženjeringa ovdje se ne mijenja genetska slika biljke već se radi o svojevrsnoj simbiozi, odnosno zajednici od koje oba organizma imaju koristi. Tako da osim što mogu djelovati kao patogeni, mikroorganizmi kao što su bakterije i gljive u ovom slučaju mogu pozitivno utjecati na rast i razvoj biljaka. Ovakve organizme koji se nalaze u biljci, ali ne izazivaju simptome biljnih bolesti nazivamo endofitima (Stone i sur., 2000). Procijenjeno je da u prirodi danas ima preko milijun vrsta endofitnih gljiva (Faeth i Fagan, 2002). Kako navode Reshma i sur. (2019) endofiti potiču rast biljaka kroz poboljšanje fiksacije dušika, proizvodnju fitohormona, solubilizaciju fosfata te poticanje tolerancije na abiotske i biotske stresove. Endofitne mikrobne populacije sintetiziraju veliku broj novih sekundarnih metabolita, uključujući spojeve s antifungalnim, antibakterijskim i insekticidnim svojstvima. Biološka kontrola biljnih patogena i insekata štetnika kultiviranih usjeva privukla je pozornost kao metoda smanjenja uporabe kemijskih pesticida u poljoprivredi. Endofiti se mogu pronaći u svakoj biljci i u raznim dijelovima biljaka te se kaže da ne postoji biljna vrsta koja ne sadrži neku vrstu endofita (Schulz i sur., 2015). Smatra se da su endofiti izvor novih prirodnih proizvoda za primjenu u biotehnologiji, medicini, poljoprivredi i industriji (Ryan i sur., 2008.; Senthilkumar i sur., 2011).

Prema Ab Rahman i sur. (2018) uz klasičnu primjenu individualnih mikroorganizama sve se više nastoji poboljšati, omogućiti i održati dugoročna kolonizacija biljaka pomoću mikrobiološkog inženjeringa kako bi se omogućilo uzgajanje biljaka poboljšanim s mikroorganizmima. Haidar i sur. (2018) navode kako je broj mikroorganizama koji se mogu primjenjivati kao biološki fungicidi u borbi protiv biljnih bolesti još uvijek vrlo ograničen. Potraga za novim mikoorganizmima i njihovim metabolitima se stoga nastavlja. Vrijednost globalnog tržišta biokontrolnih sredstava je iznosila oko 2.1 milijardu dolara 2011. godine na što je utjecala sve veća potražnja za organskim proizvodima (Velivelli i sur., 2014). Prednosti primjene mikroorganizama i njihovih metabolita u biološkoj zaštiti biljnih bolesti je što nemaju negativan učinak na zdravlje ljudi

Jelena Jelenić, doktorant, izv. prof. dr. sc. Jelena llić, Fakultet agrobiotehniđ̌kih znanosti Osijek, Vladimira Preloga 1, 31000 0sijek, Hrvatska Autor za korespodendju:jilic@fazos.hr 
i životinja, ne utječu negativno na okoliš te na korisne organizme u prirodi (Parnel i sur., 2016; Ab Rahman i sur., 2018). Hong i Park (2016) navode kako inokulacija endofitnih organizama u biljke može spriječiti pojavu simptoma bolesti uzrokovane s insektima, virusima, bakterijama, nematodama i gljivama.

U skladu s navedenim su i naša istraživanja gdje smo izolirali gljive roda Fusarium s korova u polju s predpostavkom da su mnoge od njih patogene. Korovi nisu pokazivali simptome bolesti. Uz patogenost utvrdili smo da pojedine vrste imaju pozitivan utjecaj na rast i prinos pšenice i kukuruza (Ilic i sur., 2012). Navedene endofitne Fusarium vrste s pozitivnim djelovanjem smo dalje testirali na kulturi tkiva trešnje (Ilić i sur., 2017) te utvrdili značajan pozitivan utjecaj na porast biljaka. Iste Fusarium izolate primjenili smo i u ovom istraživanju. Cilj nam je bio da utvrdimo kako endofitne gljive djeluju na porast i cjelokupno zdravstveno stanje vinove loze.

\section{Materijal i metode}

Dva različita izolata endofitne gljive Fusarium solani korištena u prethodnim istraživanjima (Ilic i sur., 2013, Ilic i sur., 2017) su uzgajana na PDA podlogama (krumpir-dekstrozni agar) tjedan dana u klima komorama. Nakon toga napravljena je suspenzija gljiva sa vodom, tako što je ostrugan micelij s PDA podloge pomoću sterilnog skalpela. Micelij se prenosi u čašu s destiliranom vodom te se sadržaj izljeva u mikser koji usitnjava gljivu. Tako pripremljena suspenzija se čuva u hladnjaku do primjene. Suspenzija gljiva se pomoću plastične boce s pumpicom nanosi na pupove vinove loze. Kontrolne biljke tretirane su destiliranom vodom.

Sadnice vinove loze sorti Lavalle i Kardinal su posađene u kaljiće s zemljom za cvijeće te je pup tretiran suspenzijom dva različita izolata endofitnih gljiva roda F. solani. Nakon dva mjeseca izmjerili smo visinu biljke te dimenzije i broj listova.

\section{Rezultati i rasprava}

Nakon pregleda vinove loze utvrđeno je da biljke tretirane s endofitnim gljivama imaju značajno veći porast i bujnije listove.

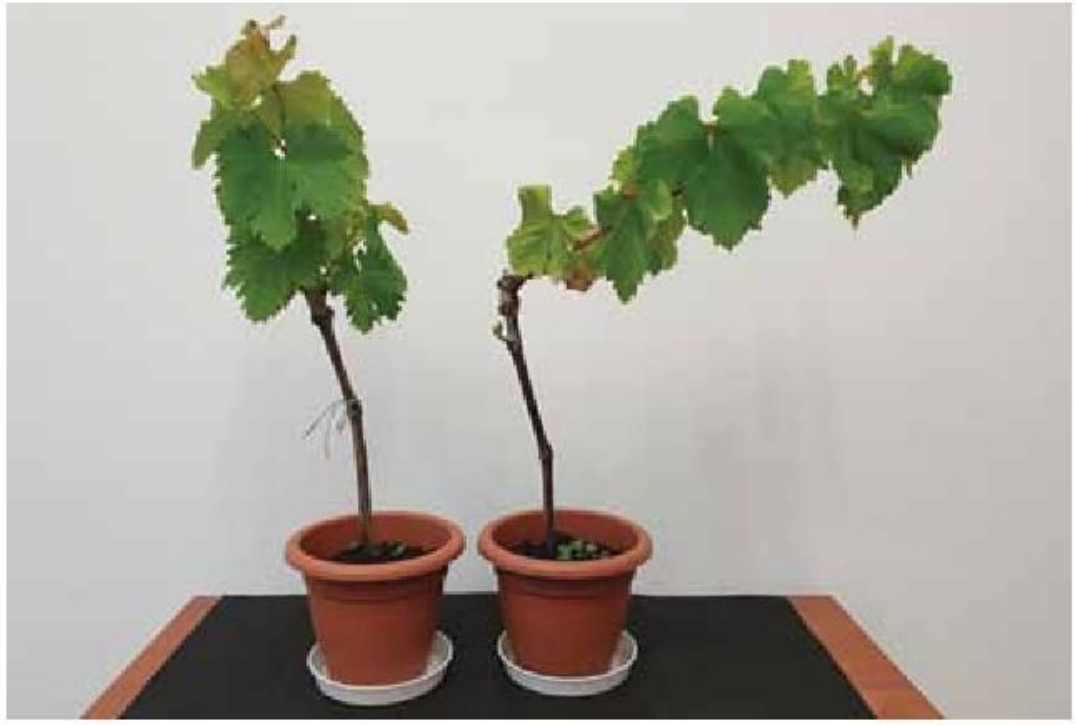

Slika 1. Sadnice vinove loze sorte Lavalle: lijevo kontrola i desno loza tretirana s endofitom F. solani I

Image 1. Grape vine seedlings of Lavalle cultivar:

left - control and right - vine treated with endophyte F. solani I 


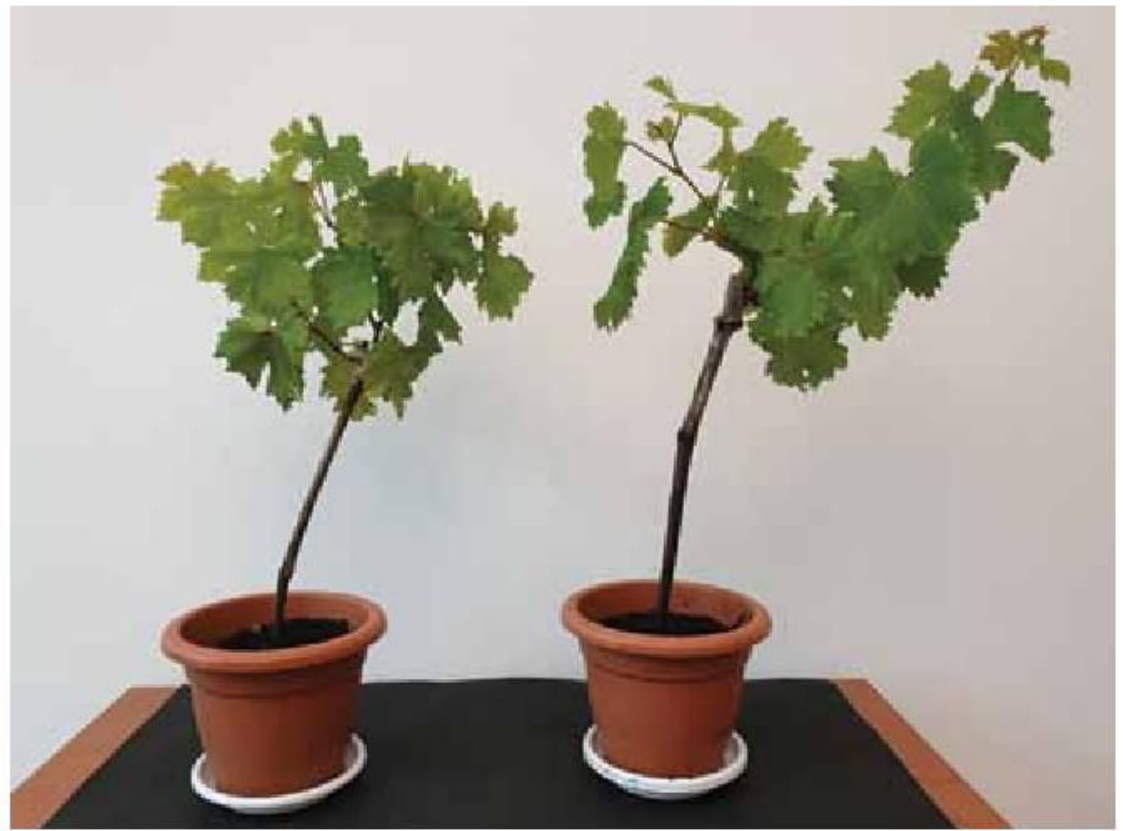

Slika 2. Sadnice vinove loze sorte Kardinal: lijevo kontrola i desno loza tretirana s endofitom $F$. solani ll

Image 2. Grape vine seedlings of Kardinal cultivar:

left - control and right - vine treated with endophyte F. solani II

S obzirom da prodiranje endofitne gljive u biljku predstavlja klasičnu infekciju s razlogom se možemo upitati da li su endofiti ustvari latentni patogeni koji će izazvati bolest u odgovarajućim uvjetima? Prema Schulz i Boyle (2005) pojam endofiti se odnosi samo na gljive u trenutku otkrivanja unutar biljke bez obzira na budući status interakcije. Do danas su razni znanstvenici utvrdili pozitivian utjecaj endofita na rast i razvitak biljaka. Yates i sur. (1997) su inokulirali zrna kukuruza s Fusarium monilliforme te uočili značajan pozitivan utjecaj na morfologiju i histologiju klijanaca kukuruza. Šišić i sur. (2017) su ispitali sposobnost tri izolata Fusarium equiseti da endofitno koloniziraju korijenje graška te utjecaj endofitnog razvoja na rast biljaka, proliferaciju patogena i bolesti korijena. Utvrdili su da F. equiseti može potaknuti rast graška i ima sposobnost mijenjanja interakcije graška i patogena korijena. Macia-Vicente i sur. (2009) su ispitali utjecaj endofitnih gljiva Fusarium equiseti i Pochonia chlamydosporia na porast i otpornost na Gaeumannomyces graminis var. tritici, uzročnika bolesti polijeganja ječma. P. chlamydosporia je pozitivno utjecala na porast biljke, a korijenje tretirano $s$. equiseti je imalo manju količinu lezija uzrokovanih patogenom G. graminis. Rezultati ovog rada sugeriraju da su i F. equiseti i $P$. chlamydosporia dugoročni korijenski endofiti koji daju povoljne učinke biljci domaćinu.

\section{Zaključak}

Optimalno razvijene biljke imaju veći potencijal rodnosti te potencijalno bolju otpornost na bolesti stoga možemo reći da ovako bolje razvijene biljke mogu dati veći i zdraviji urod. $U$ daljnjem istraživanju ćemo ispitati otpornost vinove loze tretirane s endofitima na sivu plijesan. 


\section{Literatura}

Ab Rahman, S.F.S., Singh, E., Pieterse, C.M., Schenk, P.M. (2018) Emerging microbial biocontrol strategies for plant pathogens. Plant science 267: 102-111.

Faeth, S.H., Fagan, W.F. (2002) Fungal endophytes: common host plant symbionts but uncommon mutualists. Integrative and Comparative Biology 42: 360-368.

del Carmen Orozco-Mosqueda, M., del Carmen Rocha-Granados, M., Glick, B.R., Santoyo, G. (2018) Microbiome engineering to improve biocontrol and plant growth-promoting mechanisms. Microbiological research 208: 25-31.

Haidar, R., Fermaud, M., Calvo-Garrido, C., Roudet, J., Deschamps, A. (2016) Modes of action for biological control of Botrytis cinerea by antagon istic bacteria. Phytopathologia Mediterranea55: 301-322.

Hong, C.E., Jo, S.H., Moon, J.Y., Lee, J.S., Kwon, S.Y., Park, J.M. (2015) Isolation of novel leaf-inhabiting endophytic bacteria in Arabidopsis thaliana and their antagonistic effects on phytophathogens. Plant Biotechnology Reports 9: 451-458.

Ilić, J., Ćosić, J., Jurković, D., Vrandečić, K. (2012) Pathogenicity of Fusarium spp. isolated from weeds and plant debris in eastern Croatia to wheat and maize. Poljoprivreda 18: 7-11.

Ilic, J., Cosic, J., Vrandecic, K., Dugalic, K., Pranjic, A., Martin, J. (2017) Influence of endophytic fungi isolated from symptomless weeds on cherry plants. Mycosphere 8: 18-30.

Maciá-Vicente, J.G., Rosso, L.C., Ciancio, A., Jansson, H.B., Lopez-Llorca, L.V. (2009) Colonization of barley roots by endophytic Fusarium equiseti and Pochonia chlamydosporia: effects on plant growth and disease. Annals of Applied Biology 155: 391-401.

Parnell, J.J., Berka, R., Young, H.A., Sturino, J.M., Kang, Y., Barnhart, D.M., DiLeo, M.V. (2016) From the lab to the farm: an industrial perspective of plant beneficial microorganisms. Frontiers in plant science,7: 1110.

Reshma, J., Vinaya, C., Linu, M. (2019 Agricultural Applications of Endophytic Microflora. In Seed Endophytes (pp. 385-403). Springer, Cham.

Ryan, R.P., Germaine, K., Franks, A., Ryan, D.J., Dowling, D.N. (2008) Bacterial endophytes: recent developments and applications. FEMS microbiology letters, 278: 1-9.

Stone, J.K., Bacon, C.W., White Jr, J.F. (2000) An overview of endophytic microbes: endophytism defined. In Microbial endophytes (pp. 17-44). CRC Press.

Schulz, B., Boyle, C. (2005)The endophytic continuum. Mycological research 109: 661-686.

Schulz, B., Haas, S., Junker, C., Andrée, N., Schobert, M. (2015) Fungal endophytes are involved in multiple balanced antagonisms. Current science 39-45.

Senthilkumar, M., Anandham, R., Madhaiyan, M., Venkateswaran, V., Sa, T. (2011) Endophytic bacteria: perspectives and applications in agricultural crop production. In Bacteria in Agrobiology: Crop Ecosystems (pp. 61-96). Springer, Berlin, Heidelberg.

Šišić, A., Baćanović, J., Finckh, M.R. (2017) Endophytic Fusarium equiseti stimulates plant growth and reduces root rot disease of pea (Pisum sativum L.) caused by Fusarium avenaceum and Peyronellaea pinodella. European journal of plant pathology 148: 271-282.

Velivelli, S.L., De Vos, P., Kromann, P., Declerck, S., Prestwich, B.D. (2014) Biological control agents: from field to market, problems, and challenges. Trends in biotechnology 32: 493-496.

Yates, I.E., Bacon, C.W., Hinton, D.M. (1997) Effects of endophytic infection by Fusarium moniliforme on corn growth and cellular morphology. Plant disease 81: 723-728.

\section{Application of endophytic Fusarium fungi for growth improvement of wine grape}

\section{Summary}

Endophytic organisms are increasingly being used in organic production and plant protection. The most common are fungi and bacteria which are applied to plants as biological agents for improving growth and resistance to plant diseases. In our research we preliminary examined the influence of two isolates of Fusarium solani on the growth of the grapevine varieties Cardinal and Lavalle. Wine grapes were treated with a fungal suspension in bud stage. Two months after the artificial infection the characteristics of the wine grape were measured: length of the stem and length, width and number of leaves. Significantpositive effect of endophytic fungi on the size of the stem and leaf was determined. We concluded that endophytic fungi positively affect the overall health of the plant, which indirectly reduces the possibility of disease because the plants are more resistant.

Keywords: endophytes, fungi, growth enhancement, wines 